\title{
Коричнево-мраморный клоп - новая угроза овощеводству на юге России
}

\author{
The brown marmorated stink bug is a new threat to vegetable production in the South \\ of Russia
}

\section{Митюшев И.М.}

\section{Аннотация}

Представлена информация о происхождении и географическом распространении коричнево-мраморного клопа Halyomorpha halys Stål (Hemiptera: Pentatomidae). Приведены данные об инвазивном ареале и вредоносности коричнево-мраморного клопа на юге России. Дано описание морфологических и биологических особенностей вредителя. Описаны методы мониторинга и борьбы с вредителем. Коричнево-мраморный клоп - опасный инвазивный вредитель, происходящий из восточной Азии. Он повреждает значительное количество экономически значимых растений, включая различные овощные и плодовые культуры, а также лесные и декоративные растения. В Европе вредитель впервые был выявлен в 2004 году в Швейцарии и Лихтенштейне; к 2020 году он распространился в 26 странах континента. На территории Евразийского экономического союза впервые зарегистрирован в России в 2014 году, на территории города Сочи; в 2017 году впервые обнаружен в Казахстане. Сегодня происходит формирование инвазивного ареала вредителя на юге России: он распространился в Краснодарском крае и в республике Крым. Коричнево-мраморный клоп способен питаться на более чем 300 видах растений из 49 семейств, включая различные плодовые, овощные, декоративные и лесные растения. Из овощных культур наиболее сильно повреждает томаты, перец, баклажан, огурец, фасоль, горох и кукурузу, из плодовых культур - яблоню, грушу, персик, черешню, цитрусовые, лещину, хурму и виноград. Уже в 2016-2017 годах H. halys нанес серьезный вред овощным и плодовым культурам в Краснодарском крае. Выявление очагов коричнево-мраморного клопа осуществляют методами визуального и феромонного мониторинга. Феромонный мониторинг позволяет выявлять вредителей даже при низкой численности, его осуществляют при помощи феромонных ловушек, которые размещают с мая по сентябрь. В «Государственный каталог пестицидов и агрохимикатов, разрешенных к применению на территории Российской Федерации" включено три инсектицида против этого вредителя, но препараты, разрешенные для защиты от него пасленовых и бобовых культур, сегодня в нем отсутствуют.

Ключевые слова: Halyomorpha halys, коричнево-мраморный клоп, Hemiptera, инвазивные вредители, вредители овощных культур, карантин растений, защита растений, юг России.

Для цитирования: Митюшев И.М. Коричнево-мраморный клоп - новая угроза овощеводству на юге России // Картофель и овощи. 2020. №5. C. 20-24. https://doi.org/10.25630/PAV.2020.11.69.004
Mityushev I.M.

Abstract

The article provides information on origin and world distribution of the brown marmorated stink bug, Halyomorpha halys Stål (Hemiptera: Pentatomidae). The data on the invasive range and harmfulness of the pest in the South of Russia is presented. The description of morphological and biological features of the pest is given. The pest monitoring and control measures are described. The brown marmorated stink bug is a dangerous invasive pest of East Asia origin. It damages a number of economically important plants, including various vegetable and fruit crops, as well as forestry and ornamentals. In Europe, this pest has been recorded for the first time in 2004, in Switzerland and Liechtenstein; as of 2020, it has been introduced to 26 countries of the continent. In the Eurasian Economic Union, the pest has been recorded for the first time in Russia in 2014, in the territory of Sochi; in 2017 it has been recorded for the first time in Kazakhstan. The invasive range of the pest is currently being formed in the South of Russia. The pest has spread to the Krasnodar Krai and the Republic of Crimea. The brown marmorated stink bug feeds on more than 300 plant species from 49 families. The most severely damaged vegetable crops are tomatoes, peppers, aubergine, cucumber, beans, peas and corn; among the fruit crops, the highest damage occurs in apples, pears, peaches, cherries, citrus fruit crops, hazel, persimmons, and grapes. As early as in 2016-2017, the brown marmorated stink bug caused serious damage to vegetable and fruit crops in the Krasnodar Krai. Detection of outbreaks of the brown marmorated stink bug is carried out by both visual and pheromone monitoring. Pheromone monitoring allows identifying pests even at low population densities; it is carried out using pheromone traps, which are placed on the edges of fields from May to September. The "State catalogue of pesticides and agrochemicals permitted for use on the territory of the Russian Federation" includes 3 insecticides recommended for use against this pest, but so far there are no preparations permitted for protection of solanaceous and legume crops.

Key words: Halyomorpha halys, brown marmorated stink bug, Hemiptera, invasive pests, pests of vegetables, plant quarantine, plant protection, Southern Russia.

For citing: Mityushev I.M. The brown marmorated stink bug is a new threat to vegetable production in the South of Russia. Potato and vegetables. 2020. No5. Pp. 20-24. https://doi.org/10.25630/ PAV.2020.11.69.004 (In Russ.).
( енеральная ассамблея $\mathrm{OOH}$ провозгласила 2020 год Международным годом охраны здоровья растений, который проходит под девизом: «Защитим растения - сохраним жизнь». Цель проведения этого Международного года $\mathrm{OOH}$ - повышение уровня информированности мировой общественности о проблематике в сфере каранти- на и защиты растений. Новые фитосанитарные риски связаны с инвазивными вредными организмами, которые распространяются между странами и континентами благодаря интенсификации международной торговли и путешествий: в условиях глобального изменения климата их ареал быстро расширяется, а вредоносность увеличивается. Один из таких вредных организмов - коричнево-мраморный клоп Halyomorpha halys Stål (Hemiptera: Pentatomidae), который в течение последних 20 лет распространился и акклиматизировался на разных континентах (рис. 1), при этом его распространение происходило с растительными грузами, контейнерами, транспортными средствами и в багаже путешествен- 


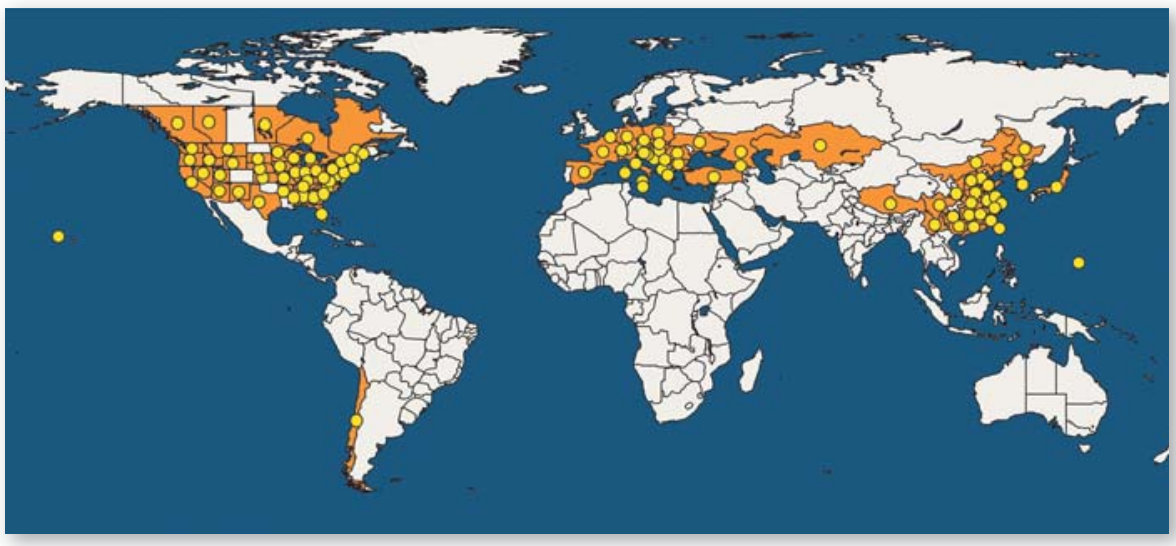

Рис. 1. Географическое распространение коричнево-мраморного клопа [4]

ников. В России этот вредитель был впервые выявлен в 2014 году [1], сегодня он представляет угрозу растениеводству на юге страны [2].

Коричнево-мраморный клоп аборигенный вид восточноазиатского региона: его естественный ареал включает территорию Китая (кроме Синьцзян-Уйгурского автономного района и провинции Цинхай), Мьянмы, Вьетнама, Северной и Южной Кореи, Японии (кроме о. Хоккайдо), Тайваня [3]. С грузами из Китая клоп был впервые завезен в США в середине девяностых годов XX века, где стал серьезным вредителем широкого круга культурных растений; сегодня он отмечен здесь в 46 штатах [4]. H. halys также зарегистрирован в Канаде (провинции Альберта, Британская Колумбия, Квебек, Манитоба, Онтарио). В 2017 году H. halys был обнаружен в Чили. На европейском континенте $H$. halys впервые был выявлен в 2004 году в Швейцарии и Лихтенштейне. К 2020 году вредитель отмечен в Германии, Греции (первое обнаружение в 2011 году), Италии, Франции (2012 год), Венгрии (2013 год), России, Румынии (2014 год), Абхазии, Австрии, Сербии (2015 год), Болгарии, Грузии, Испании, Казахстане, Словакии (2016 год), Словении, Турции, Хорватии (2017 год), Албании, Боснии и Герцеговине, Мальте, Польше, Украине, Чехии (2018 год) [4].

Цель исследования - провести анализ данных о распространении и вредоносности коричнево-мраморного клопа на юге России, систематизировать основные методы мониторинга и защиты овощных культур от вредителя.

Условия, материалы и методы исследований
Исследования ли в 2014-2019 годах, в условиях Черноморского побережья и Приазовья Краснодарского края. Имаго, личинок и яйцекладки клопа на кормовых растениях выявляли визуальным методом, фотографический материал был получен в 2016 и 2019 годах, с использованием цифровой камеры Fujifilm X-A2. Были проанализированы новейшие отечественные и зарубежные литературные источники, посвященные распространению и вредоносности $H$. halys в Европе и на юге России, включая собственные работы автора. При составлении таблицы с описанием личинок H. halys разных возрастов, помимо литературных источников, был проанализирован материал, собранный автором.

\section{Результаты исследований}

Коричнево-мраморный

клоп включен в Единый перечень карантинных объектов Евразийского экономического союза (действует на

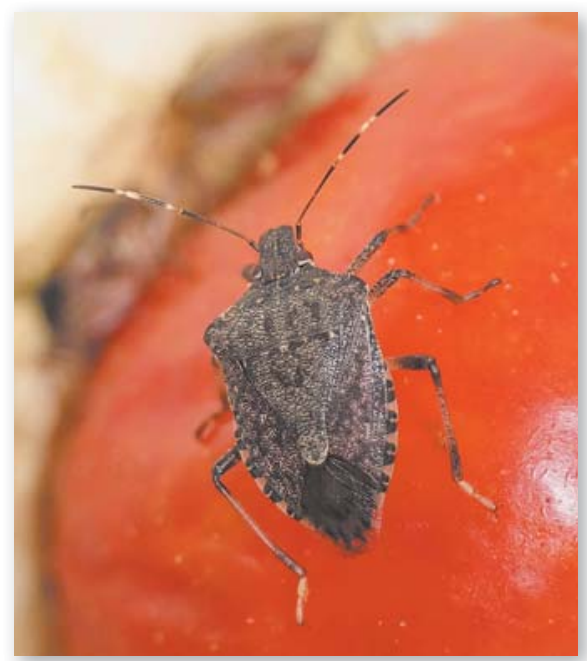

Рис. 2. Имаго H. halys на плоде томата (фото И.М. Митюшева) территории Армении, Белоруссии, Казахстана, Киргизии и России), как вредитель, отсутствующий на территории ЕАЭС [5]. Вместе с тем, в России коричнево-мраморный клоп был впервые выявлен в 2014 году на территории Сочи [1]. Сегодня происходит формирование инвазивного ареала вредителя на юге России: он распространился в Краснодарском крае и в республике Крым [2, 6, 7]. Предполагают, что в 2013-2014 годах вредитель был завезен в Сочи с посадочным материалом декоративных растений из Италии или Греции [8].

Коричнево-мраморный клоп способен питаться на более чем 300 видах растений из 49 семейств, включая различные плодовые, овощные, декоративные и лесные растения [2, $4,8,9,10]$. Из овощных культур наиболее сильно повреждает томаты, перец, баклажан, огурец, фасоль, горох, и кукурузу, из плодовых - яблоню, грушу, персик, черешню, цитрусовые, лещину, хурму и виноград. Уже в 2016-2017 годах H. halys нанес серьезный вред овощным и плодовым культурам в Краснодарском крае $[2,8]$. Имаго и нимфы $H$. halys питаются на листьях и плодах, вызывая образование некротических пятен и опробковение поврежденных участков, а также вдавлений и деформаций плодов томата, перца, баклажана, огурца, бобовых культур; початки кукурузы сильно деформируются, на них образуются щуплые семена $[2,10]$. При высокой численности вредителя, менее 10\% плодов бобовых остаются неповрежденными к уборке, при этом в каждом из бобов повреждено минимум одно семя [10]. Урожайность и качество плодов снижаются, они усыхают, загнивают или опадают. Декоративные и лесные растения также служат кормовой базой для вредителя, в новых местах обитания на них происходит нарастание численности $H$. halys, в дальнейшем возможна миграция клопов в агроценозы. В местах массового размножения $H$. halys также имеет статус досаждающего вредителя: имаго в больших количествах мигрируют на зимовку в различные постройки и жилища, вызывая у людей беспокойство.

Тело имаго $H$. halys широкоовальной формы, слегка уплощенное, 1217 мм в длину, голова имеет прямоугольную форму [9]. Общая окраска тела насекомого сверху - различные оттенки коричневого; голова, переднеспинка и щиток имеют более 


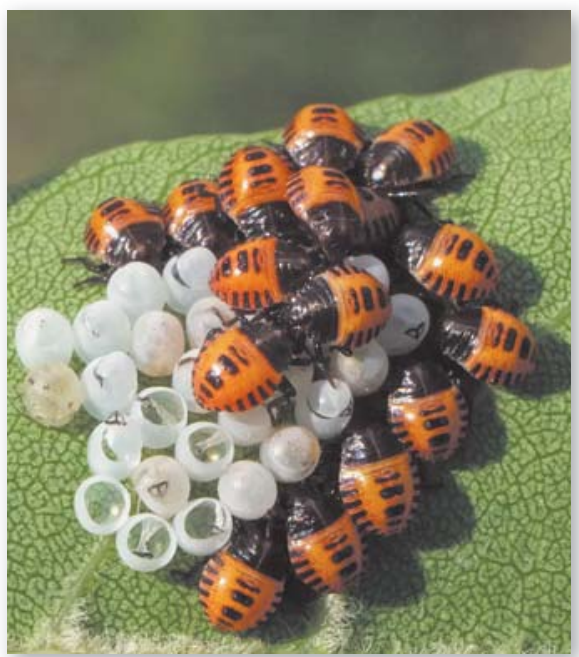

Рис. 3. Яйцекладка и отродившиеся личинки I возраста H. halys (фото И.М. Митюшева)

светлые вкрапления и крупную черную пунктировку, что визуально создает мраморный рисунок (рис. 2). Надкрылья имеют красноватый оттенок, также с крупной пунктировкой. Нижняя сторона тела - бледно-желтая, иногда с серыми или черными крапинками. По краю брюшка имеются чередующиеся черные и белые треугольные пятна. Основание и вершина IV и основание V члеников антенны белые. Ноги бледно-желтые, с многочисленными мелкими темными точками, вершина бедра, основание и вершина голени коричневые.

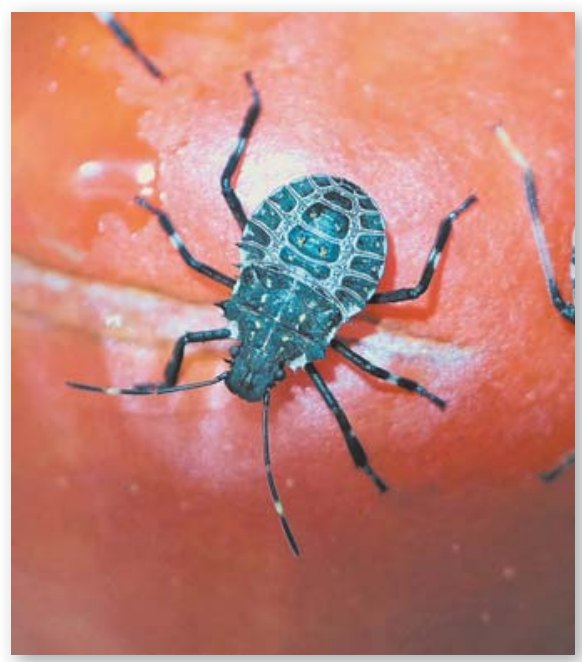

Рис. 4. Личинка H. halys IV возраста (фото И.М. Митюшева)

Яйца эллиптической формы, белые, длиной 1,6 мм, диаметром 1,3 мм, на верхней стороне яйца заметен черный Т-образный эмбриональный зубец. Яйцекладка состоит из 20-30 яиц, находится на нижней стороне листьев кормовых растений (рис. 3). Личинка проходит пять возрастов, при этом личинки разных возрастов отличаются по внешнему виду (рис. 3, 4, 5); их основные признаки приведены в таблице.

Скорость развития $H$. halys зависит от температуры воздуха, нижний порог развития составляет $13,4^{\circ} \mathrm{C}$

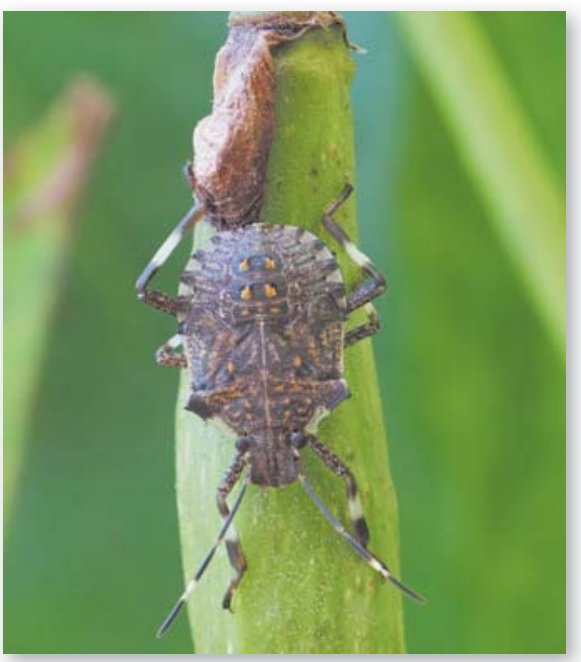

Рис. 5. Личинка H. halys V возраста (фото И.М. Митюшева)

Отличительные признаки личинок $H$. halys разных возрастов $[1,2,9]$

\begin{tabular}{|c|c|c|c|c|}
\hline Морфологические особенности & Возраст личинок & Длина тела, мм & $\begin{array}{c}\text { Наличие шипов по } \\
\text { краю тела }\end{array}$ & $\begin{array}{c}\text { Наличие зачатков } \\
\text { крыльев }\end{array}$ \\
\hline $\begin{array}{l}\text { Тело эллиптическое, выпуклое. Голова треугольная, } \\
\text { с округлыми краями. Голова, грудь, ноги - черные, } \\
\text { брюшко - оранжево-красное, с черными вытянуты- } \\
\text { ми пятнами в центре и по краям брюшных сегмен- } \\
\text { тов, глаза темно-красные, антенны красно-черные }\end{array}$ & I (рис. 3) & $2,4 \mathrm{MM}$ & Нет & Нет \\
\hline $\begin{array}{l}\text { Тело яйцевидное, слегка уплощенное. Голова пря- } \\
\text { моугольная, с короткими шипами перед глазами. } \\
\text { Голова, грудь, ноги - черные, брюшко - беловатое, } \\
\text { с мелкими красноватыми пятнами и полосами на } \\
\text { границах брюшных сегментов, с крупными черными } \\
\text { вытянутыми пятнами в центре и по краям брюш- } \\
\text { ных тергитов; глаза красно-коричневые. Антенны } \\
\text { красно-черные, вершина III членика антенны - белая }\end{array}$ & II & $3,7 \mathrm{~mm}$ & $\begin{array}{l}\text { Имеются шипы по } \\
\text { краю передне-, сред- } \\
\text { не- и заднегруди, I и II } \\
\text { сегментов брюшка }\end{array}$ & Нет \\
\hline $\begin{array}{l}\text { Тело грушевидное, уплощенное. Форма и окраска } \\
\text { головы, окраска глаз, груди как у личинок II воз- } \\
\text { раста. Окраска брюшка более темная, чем во II } \\
\text { возрасте. Ноги черные, середина голеней белая }\end{array}$ & III & $5,5 \mathrm{~mm}$ & $\begin{array}{l}\text { Имеются шипы по } \\
\text { краю передне-, сред- } \\
\text { не- и заднегруди, I и II } \\
\text { сегментов брюшка }\end{array}$ & $\begin{array}{l}\text { Слабо выражены, не } \\
\text { доходят до передне- } \\
\text { го края I брюшного } \\
\text { сегмента }\end{array}$ \\
\hline $\begin{array}{l}\text { Тело грушевидное, уплощенное. Окраска более } \\
\text { темная, чем в III возрасте, серовато-коричневая. } \\
\text { Антенны красно-черные, основание IV и вершина } \\
\text { III члеников антенны желто-белые. Ноги черные, } \\
\text { середина голеней желто-белая }\end{array}$ & IV (рис. 4) & $8,5 \mathrm{~mm}$ & $\begin{array}{l}\text { Имеются шипы по } \\
\text { краю передне-, сред- } \\
\text { не- и заднегруди, I и II } \\
\text { сегментов брюшка }\end{array}$ & $\begin{array}{c}\text { Хорошо заметны, } \\
\text { заходят за середину I } \\
\text { брюшного сегмента }\end{array}$ \\
\hline $\begin{array}{l}\text { Тело грушевидное, сильно уплощенное. Общая } \\
\text { окраска серовато-коричневая, с более светлыми } \\
\text { пятнами. На голове, груди и брюшке заметны } \\
\text { бледно-оранжевые пятна. Ноги черно-коричне- } \\
\text { вые, середина голеней белая }\end{array}$ & $V$ (рис. 5) & $12 \mathrm{~mm}$ & $\begin{array}{l}\text { Имеется по } 4 \text { шипа по } \\
\text { краям переднегруди }\end{array}$ & $\begin{array}{l}\text { Хорошо заметны, за- } \\
\text { ходят за середину III } \\
\text { брюшного сегмента }\end{array}$ \\
\hline
\end{tabular}

[11], оптимум - в диапазоне 20$30{ }^{\circ} \mathrm{C}$ [12]. Развитие одного поколения $H$. halys при $20{ }^{\circ} \mathrm{C}$ продолжается 76,7 дней, при $30{ }^{\circ} \mathrm{C}-33,6$ дней [12]. В условиях Китая развивается 1-2 поколения $H$. halys за год, в зависимости от климатических условий. Потенциальный инвазивный ареал в Европе, где $H$. halys будет иметь высокую вредоносность, расположен между 40-й и 50-й параллелями с.ш. [13], в России эта зона включает большую часть Южного и Северо-Кавказского федеральных округов [2]. В районе г. Сочи

Имеются шипы по Слабо выражены, не

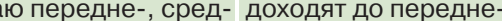
- и заднегруди, I и II го края I брюшного

Имеются шипы по

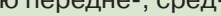
- и заднегруди, І и сегментов брюшка брюшного сегмента 


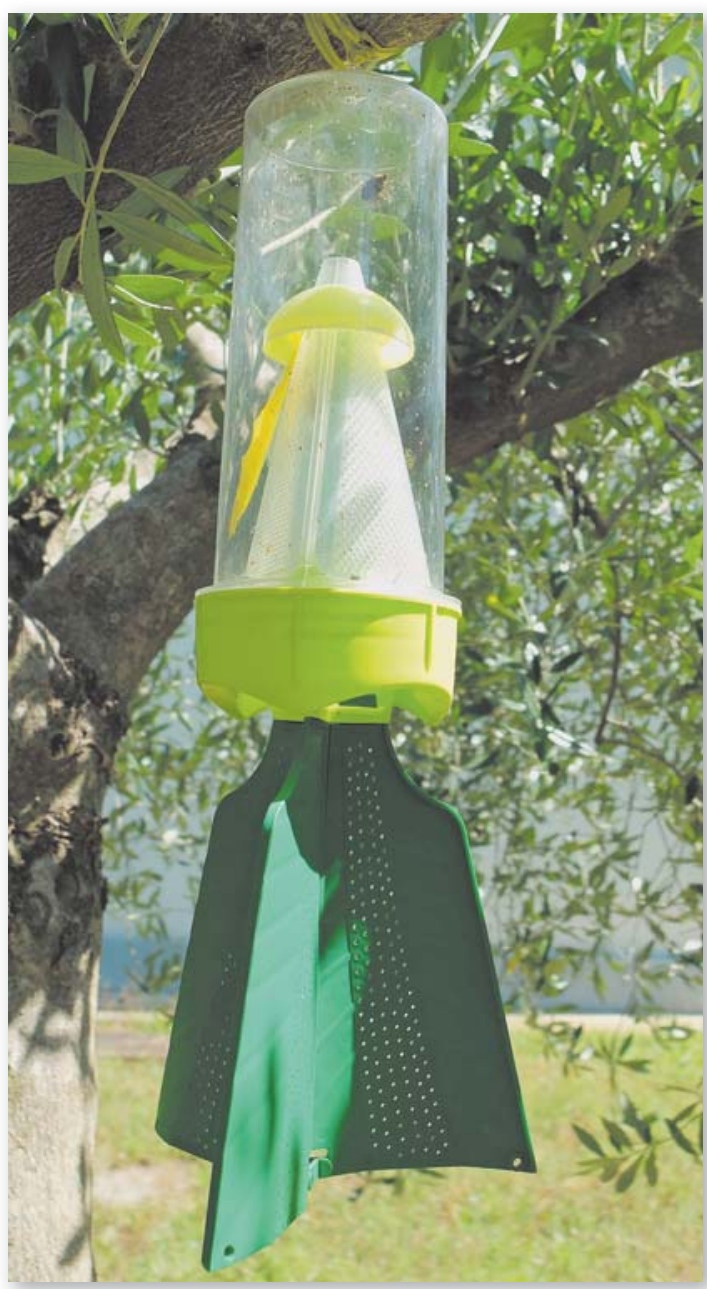

Рис. 6. Феромонная ловушка (фото И.М. Митюшева)

H. halys успешно перезимовывает и дает два поколения за сезон [2, 11]; на Черноморском побережье Краснодарского края и южном берегу Крыма для него отмечается высокая вредоносность. На остальной территории Краснодарского края и республики Крым, в Ставропольском крае, южных районах Ростовской и Астраханской областей и республики Калмыкия, а также регионах Северо-Кавказского федерального округа $H$. halys потенциально может перезимовывать и развиваться в 1-2 поколениях за сезон; в этой зоне прогнозируется средний уровень вредоносности. Севернее 50-й параллели с.ш., в условиях Курской, Воронежской, севера Волгоградской и юга Саратовской областей, возможна только неустойчивая акклиматизация вредителя [2].

Зимуют имаго $H$. halys, как правило, в массовых скоплениях,- под корой крупных пней или в трухлявых стволах, под опавшими лис- тьями; в сельской и городской местности часто забираются в различные строения и жилища. Выход из диапаузы наблюдается в III декаде апреля - II декаде мая, в течение 1-2 недель; дополнительное питание происходит при температуре не ниже $17^{\circ} \mathrm{C}$, затем имаго спариваются. Самка откладывает яйца в течение 2-3 месяцев, по 1540 яиц за раз, с интервалом 5-14 дней. Общая плодовитость самок - до 250-300 яиц. Эмбриональное развитие яиц длится 5-7 дней. В зависимости от температуры, в среднем одно поколение клопа развивается 40-60 дней.

Выявление очагов коричнево-мраморного клопа осуществляют методами визуального и феромонного мониторинга. Визуальный мониторинг проводят путем осмотра кормовых растений: на овощных культурах осматривают нижнюю сторону листьев, листовые розетки, бутоны, цветки, плоды; особое внимание уделяют краевым участкам полей, соседствующим с декоративными питомниками, плодовыми насаждениями и лесополосами. Феромонный мониторинг позволяет выявлять вредителей даже при низкой численности [14]. Его осуществляют при помощи бесклеевых феромонных ловушек, которые с мая по сентябрь размещают на краях полей овощных культур, на деревья, кустарники, столбы или шпалеры, на высоте 1,7 м над уровнем почвы (рис. 6). В качестве аттрактанта в этих ловушках используют синтетический аналог агрегационного феромона вредителя, который привлекает как личинок II-V возрастов, так и имаго обоих полов. В условиях Краснодарского края и Крыма, используют 1 ловушку на 1-4 га, а в регионах, где вредитель не отмечен - 1 ловушку на 100 га. При обнаружении очагов коричнево-мраморного клопа, проводят обработки инсектицидами.

Массовый отлов при помощи феромонных ловушек наиболее эффективен в августе и сентябре и наиболее приемлем для приусадебных участков [14]. В зонах массового распространения $H$. halys, размещают не менее 5 ловушек на площадь до 1 га: ловушки размещают по пери- метру участка, расстояние между ловушками - не менее 50 м. При увеличении площади участка, количество ловушек пропорционально увеличивают. На приусадебных участках ловушки следует размещать по краям, на столбах, шпалерах или на дикорастущих деревьях.

На небольших участках, при высокой численности клопа, возможен ручной сбор и уничтожение яйцекладок, личинок и имаго. Ручной сбор имаго клопа также целесообразен после ухода клопа на зимовку в хозяйственные постройки [2]. Для большей эффективности этого приема, в неотапливаемых помещениях (склады, сараи, подвалы и т.п.) размещают коробки, заполненные гофрированным картоном или бумагой. После заселения их клопами (в октябре - ноябре), коробки сжигают.

Применение инсектицидов - наиболее эффективный способ борьбы с коричнево-мраморным клопом [2]. В «Государственный каталог пестицидов...» в настоящее время включено 3 препарата, рекомендованных против данного вредителя [15], из них только 1 препарат, Эсперо, КС (д.в. имидаклоприд + альфа-циперметрин), разрешен для защиты кукурузы (0,1-0,2 л/га), для наземного и авиационного опрыскивания [15]. Инсектициды, разрешенные для защиты пасленовых и бобовых культур от $H$. halys, в настоящее время в «Государственном каталоге пестицидов...» отсутствуют. Вместе с тем, ряд препаратов, разрешенных к применению на овощных культурах против других вредителей, показали высокую эффективность и против $H$. halys: Алиот, КЭ (д.в. малатион) - томат и капуста; Брейк, МЭ (д.в. лямбда-цигалотрин) - горошек овощной, томат, капуста; Клипер, КЭ (д.в. бифентрин) - томат и огурец, и др. [2].

\section{Выводы}

Коричнево-мраморный клоп серьезный инвазивный вредитель широкого круга культурных растений, распространившийся из восточноазиатского региона в Европу, США, Среднюю и Малую Азию, Чили, Грузию, Россию. Методы контроля включают визуальный и феромонный мониторинг, отлов феромонными ловушками и ручной сбор, применение инсектицидов. На сегодняшний день в России для применения против этого вредителя разрешено три препарата, причем для защиты пасленовых и бобовых не разрешен ни один. 


\section{Библиографический список}

1.Митюшев И.М. Первый случай обнаружения клопа Halyomorpha halys Stål на территории Российской Федерации // Мониторинг и биологические методы контроля вредителей и патогенов древесных растений: от теории к практике. Материалы Всероссийской конференции с международным участием. Москва, 18-22 апреля 2016 г. Красноярск: ИЛ СО РАН, 2016. С. 147-148.

2.Карпун Н.Н. и др. Коричнево-мраморный клоп Halyomorpha halys Stål в России: распространение, биология, идентификация, меры борьбы. М., 2018. 28 с.

3.Wang H.J., Liu G.Q. Hemiptera: Scutelleridae, Tessaratomidae, Dinindoridae and Pentatomidae // Insect Fauna of Middle-West Qinling Range and South Mountains of Gansu Province: book (X.-K. Yang, Ed.). Sci. Press, 2005. Pp. 279-292.

4.Halyomorpha halys // EPPO Global Database. [Электронный ресурс]. URL: https://gd.eppo.int/taxon/HALYHA. Дата обращения: 16.04.2020.

5.Единый перечень карантинных объектов Евразийского экономического союза с изменениями и дополнениями от 8 августа 2019 г. [Электронный ресурc]. URL: https://vniikr.ru/edinyijperechen-karantinnyix-obektov-evrazijskogo-ekonomicheskogosoyuza. Дата обращения: 16.04.2020.

6.Карантинные фитосанитарные зоны. Южное межрегиональное управление Федеральной службы по ветеринарному и фитосанитарному надзору. [Электронный ресурс]. URL: http://rsn. krasnodar.ru/novosti/novosti2/5352. Дата обращения: 16.04.2020.

7.Стрюкова Н.М., Стрюков А.А. Первое обнаружение коричнево-мраморного клопа в Крыму // Устойчивое ноосферное развитие: сборник тезисов докладов научной межвузовской конференции, посвященной 156-летию со дня рождения В.И. Вернадского. Симферополь, 2019. С. 68-70.

8.Musolin D.L., Konjević A., Karpun N.N., Procenko V.Ye., Ayba L.Ya., Saulich A.Kh. Invasive brown marmorated stink bug Halyomorpha halys (Stål) (Heteroptera: Pentatomidae) in Russia, Abkhazia, and Serbia: history of invasion, range expansion, early stages of establishment, and first records of damage to local crops. ArthropodPlant Interactions. 2018. Vol. 12 (4). Pp. 517-529. DOI: 10.1007/ s11829-017-9583-8.

9.Hoebeke E.R., Carter M.E. Halyomorpha halys (Stål) (Heteroptera: Pentatomidae): A polyphagous plant pest from Asia newly detected in North America // Proceedings of the Entomological Society of Washington. 2003. 105 (1). Pp. 225-237.

10.Vétek G., Korányi D. Severe damage to vegetables by the invasive brown marmorated stink bug, Halyomorpha halys (Hemiptera: Pentatomidae), in Hungary // Periodicum biologorum. 2017. Vol. 119. No 2. Pp. 131-135. DOI: 10.18054/pb.v119i2.4935.

11.Musolin D.L., Dolgovskaya M.Yu., Protsenko V.Ye., Karpun N.N., Reznik S.Ya., Saulich A.Kh. Photoperiodic and temperature control of nymphal growth and adult diapause induction in the invasive Caucasian population of the brown marmorated stink bug, Halyomorpha halys // Journal of Pest Science. 2019. Vol. 92. No2. Pp. 621-631.

12. Haye T., Abdallah S., Gariepy T., Wyniger D. Phenology, life table analysis and temperature requirements of the invasive brown marmorated stink bug, Halyomorpha halys, in Europe // Journal of Pest Science. 2014. 87. Pp. 407-418.

13.Zhu G., Bu W., Gao Y., Liu G. Potential geographic distribution of brown marmorated stink bug invasion (Halyomorpha halys) // PLoS ONE. 2012. 7 (2): e31246. https://doi.org/10.1371/journal.pone.0031246.

14.Митюшев И.М. Феромоны насекомых и их применение в защите растений: Учебное пособие. М.: Издательство РГАУ-МСХА, 2015. 124 c.

15.Государственный каталог пестицидов и агрохимикатов, разрешенных к применению на территории Российской Федерации. Часть І. Пестициды. Издание официальное. М.: Минсельхоз России, 2020. 853 с. [Электронный ресурc]. http://www.mcx.ru. Дата обращения: 16.04.2020.

\section{References}

1.Mityushev I.M. The first record of the brown marmorated stink bug, Halyomorpha halys Stål, in the Russian Federation. Monitoring and biological control methods of woody plant pests and pathogens: from theory to practice. Proceedings of International conference. Moscow. April 18-22. 2016. Krasnoyarsk. SIF SB RASc. 2016. Pp. 147-148. (In Russ.). 2.Karpun N.N. et al. The Brown marmorated stink bug in Russia: distribution, biology, identification, control. Moscow, 2018. 28 p. (In Russ.).

3.Wang H.J., Liu G.Q. Hemiptera: Scutelleridae, Tessaratomidae, Dinindoridae and Pentatomidae. Insect Fauna of Middle-West Qinling Range and South Mountains of Gansu Province: book (X.-K. Yang, Ed.). Sci. Press, 2005. Pp. 279-292.

4. Halyomorpha halys // EPPO Global Database. [Web resource]. URL: https://gd.eppo.int/taxon/HALYHA. Access date: 16.04.2020.

5.The Common List of plant quarantine pests of the Eurasian Economic Union with additions and changes d/d 08.08.2019. [Web resource]. URL: https://vniikr.ru/edinyij-perechen-karantinnyix-obektovevrazijskogo-ekonomicheskogo-soyuza. Access date: 16.04.2020 (In Russ.).

6.Quarantine phytosanitary zones. Southern interregional authority of Federal service for veterinary and phytosanitary surveillance. [Web resource]. URL: http://rsn.krasnodar.ru/novosti/novosti2/5352. Access date: 16.04 .2020 (In Russ.).

7.Stryukova N.M., Stryukov A.A. First record of the brown marmorated stink bug in Crimea. Sustainable noosphere development: Proceeding of Scientific Interuniversity Conference, Simferopol, 19.03.2019. Simferopol. 2019. Pp. 68-70. (In Russ.).

8.Musolin D.L., Konjević A., Karpun N.N., Procenko V.Ye., Ayba L.Ya., Saulich A.Kh. Invasive brown marmorated stink bug Halyomorpha halys (Stål) (Heteroptera: Pentatomidae) in Russia, Abkhazia, and Serbia: history of invasion, range expansion, early stages of establishment, and first records of damage to local crops. ArthropodPlant Interactions. 2018. Vol. 12 (4). Pp. 517-529. DOI: 10.1007/ s11829-017-9583-8

9.Hoebeke E.R., Carter M.E. Halyomorpha halys (Stål) (Heteroptera: Pentatomidae): A polyphagous plant pest from Asia newly detected in North America. Proceedings of the Entomological Society of Washington, 2003. 105(1). Pp. 225-237.

10.Vétek G., Korányi D. Severe damage to vegetables by the invasive brown marmorated stink bug, Halyomorpha halys (Hemiptera: Pentatomidae), in Hungary. Periodicum biologorum. 2017. Vol. 119. № 2. Pp. 131-135. DOI: $10.18054 /$ pb.v119i2.4935.

11.Musolin D.L., Dolgovskaya M.Yu., Protsenko V.Ye., Karpun N.N., Reznik S.Ya., Saulich A.Kh. Photoperiodic and temperature control of nymphal growth and adult diapause induction in the invasive Caucasian population of the brown marmorated stink bug, Halyomorpha halys. Journal of Pest Science. 2019. Vol. 92. № 2. Pp. 621-631. https://doi. org/10.1007/s10340-019-01080-1

12. Haye T., Abdallah S., Gariepy T., Wyniger D. Phenology, life table analysis and temperature requirements of the invasive brown marmorated stink bug, Halyomorpha halys, in Europe. Journal of Pest Science. 2014. 87. Pp. 407-418.

13.Zhu G., Bu W., Gao Y., Liu G. Potential geographic distribution of brown marmorated stink bug invasion (Halyomorpha halys). PLoS ONE. 2012. 7 (2): e31246. https://doi.org/10.1371/journal.pone.0031246

14. Mityushev I.M. Insect pheromones and their application in plant protection: Textbook. Moscow: Publishing house of RSAU-MTAA, 2015. 124 p. (In Russ.).

15.State catalogue of pesticides and agrochemicals permitted for use on the territory of the Russian Federation. Part I. Pesticides. Official Edition. Moscow: Ministry of Agriculture of the Russian Federation. 2020. 853 p. [Web resource]. URL: http://www.mcx.ru. Date of access: 16.04.2020 (In Russ.).

\section{Об авторе}

Митюшев Илья Михайлович, канд. биол. наук, доцент кафедры защиты растений, ФГБОУ ВО РГАУ-МСХА имени К.А. Тимирязева. E-mail: mityushev@mail.ru

\section{Author details}

Mityushev I.M., Cand. Sci. (Biol.), associate professor, Department of Plant protection, Russian State Agrarian University - Moscow Timiryazev Agricultural Academy. E-mail: mityushev@mail.ru 